\title{
Cameroon and the Gender Issue
}

\author{
Laurentine Mouchingam Mefire1, Bilkis Vissandjée², Gilles Bibeau³ \\ ${ }^{1}$ Department of Anthropology, Université de Montréal, Montreal, Canada \\ ${ }^{2}$ Faculty of Nursing, Université de Montréal, Montreal, Canada \\ ${ }^{3}$ Department of Anthropology, Université de Montréal, Montreal, Canada \\ Email: mefire.laurentine@gmail.com, bilkis.vissandjee@umontreal.ca, gilles.bibeau2@sympatico.ca
}

How to cite this paper: Mefire, L. M., Vissandjée, B., \& Bibeau, G. (2017). Cameroon and the Gender Issue. Advances in Anthropology, 7, 34-45.

https://doi.org/10.4236/aa.2017.71004

Received: December 7, 2016

Accepted: February 11, 2017

Published: February 14, 2017

Copyright (๑) 2017 by authors and Scientific Research Publishing Inc. This work is licensed under the Creative Commons Attribution International License (CC BY 4.0).

http://creativecommons.org/licenses/by/4.0/

\begin{abstract}
As African states have entered the global trend for women's emancipation, many have then set up a "national gender policy". However, that process seems to vary by country and by degree of cultural integration. The purpose of this article is to point out the obstacles blocking the implementation of the gender policy and negatively affect its social appropriation. It raises out the essential innovative mechanisms and argues that the process would need to be driven from the bottom up with direct involvement of target groups. From an anthropological perspective this article regarded at the Cameroon's situation. So, an ethnographic study carried on during the recent years in Cameroon allowed questioning the relationships between central and decentralised State services, associative groups and political parties. As a matter of result it concludes that there is a need of reshaping those deontic links so as to guarantee that the gender policy document will not end up being just a theoretical text kept in closets. Concerning political parties they should relayed the promotion of the national gender policy. Furthermore strategic partnerships between State services and associative groups should be more coherent as well.
\end{abstract}

\section{Keywords}

Developmental Policies, Civil Society, Gender and Diversity, Governance and Public Policy, Sub-Saharan Africa

\section{Introduction}

Public policies have become instruments of "governmentality" and biopower (Foucault, 1986, 1994) as well as socio-political and socio-cultural tools in the organization of contemporary societies (Shore, 2012; Shore \& Wright, 1997a, 1997b; Wedel, Shore, Feldman, \& Lathrop, 2005). They are reflected today in almost all areas of social reality. As a result, it would hardly be possible to ignore 
or to avoid their influence. Individuals are therefore ordered based on public policies even if they have little awareness or little control over the mechanisms and processes involved. Public policies participate in the evolution of governance systems; they help reshape the relationship between the individual and society; We want to contribute to the questioning of this relationship; to examine and to understand it.

It is in this perspective that our approach is at the center of current issues such as meaning and interpretation, rhetoric and discourse, ideology and consciousness, power, norms and institutions. Our anthropological outlook on public policies is an ethnoanalysis of the social appropriation of gender policies. Now central to the analysis of social issues, the concept of gender has imposed itself as a category of action for public policies. These public policies gradually undergo various modifications so as to favor a "gender perspective" in institutions and social programs.

The intensification of a "gendered" militancy has created a momentum in Africa, as elsewhere (Caulier, 2014) ${ }^{1}$. Thus, the issue of gender equality is becoming transversal to national public policies (Burkina Faso, 2009; République de Guinée, 2011; République du Benin, 2008; République du Burundi, 2012; République du Cameroun, (a); République du Mali), and is indeed a way for some African countries to maintain development aid. "Many African governments have adopted gender equality as a means to promote their self-image in order to secure further development assistance, but without necessarily being committed to the political project" (Egbe Orock, 2007). In fact, "gender approach" is advocated by the developmentalist machine ${ }^{2}$ as being an effigy of "good governance" that ensures inclusion, solidarity and social cohesion.

All this being said, the social appropriation and implementation of national public policies could not be taken for granted because they are not self-evident. Several elements obstruct these policies, as is highlighted by the Cameroonian context examination. This paper therefore asks how the Cameroon's National Gender Policy fits into the social reality of women and men of this country. Thus it contributes to the understanding of gender equality issues and even demystifying the misunderstood message about it. Besides it invites to reflect on culturally appropriate strategies for the implementation of the National Gender Policy of Cameroon's programs.

Beyond the difficulties of research at the conceptual, methodological and ethnographic levels, it is important to underline the significance of this research paper. Conceptually, the theoretical framework focusing on gender anthropology and anthropology of public policies has explored the structural dynamics in Africa that promote (or not) the understanding, interpretation and appropriation of public policies. The ethnographic approach has helped to translate the perceptions of

${ }^{1}$ Describing the reality of mexican context, Mathieu Caulier demonstrates how the militantism for the gender approach was propitious for the modification of public policies and for the creation of institutions and social programs adopting a gender perspective.

${ }^{2}$ The example of financial international institutions and international Non-Governmental Organizations. 
the actors. Concerning the practical social significance, this article adds value to research on gender relations (mainly in Africa). It enriches existing knowledge on issues related to the status of women in Africa.

\section{Historical and Institutional Framework of the National Gender Policy of Cameroon (NGPC)}

In the global movement of the gender approach and the commitment of Cameroon to join that approach, the state has put in place a policy called National Gender Policy. One may believe that this policy is a tool for planning and implementing government initiatives to promote equality and equity between the sexes in all socioeconomic, political or cultural domains. To consolidate this policy and grant it a high priority, the President of the Republic of Cameroon, in the inaugural speech delivered on October 4, 2011 during his presidential election campaign, states: “(...) Notre Septennat sera centré sur (...) la promotion de la condition féminine pour parvenir à l'égalité des droits entre hommes et femmes..." (Our Septennat will focus on the promotion of the status of women to achieve equal rights between men and women "(Excerpt from National Gender Policy of Cameroon. Loose translation).

Determined to put into practice its internationally recognised commitment on the promotion of gender equality and equity, Cameroon has ratified several international, regional and sub-regional legal instruments on the protection of women's rights. Among these instruments, there are treaties, conventions, covenants and declarations, promoting the principles of equality and non-discrimination between women and men in different areas of social life, including education, health, the economy and employment. It is in this perspective that Cameroon's national policy documents have incorporated resolutions and recommendations resulting from international meetings on women's issues. In this respect, the formulation of the NGPC is revealing. For international conferences, Cameroon has taken part in numerous meetings held on women's issues ${ }^{3}$ (United Nations, 2000, $1995,1994,1993,1992,1985,1980,1975)$. This normative framework has influenced the design of national policies for the advancement of women in Cameroon.

In 1997, Cameroon developed and adopted its first policy paper on the advancement of women, defining government priorities and strategies related to

\footnotetext{
${ }^{3}$ The Mexico conference in 1975 bringing in front of the scene the women condition in the society by according attention to the redefinition of men and women's roles. The Copenhague conference in 1980 discussing, in between others, the guarantees of women's right to property, land control, inheritance. The Nairobi conference in 1985 principally based on the participation of women in politics. The Rio conference in 1992 stating the prominent role of women in the management of environment. The Vienna conference in 1993 acknowledging the rights of women and girl as a full part of universal human being rights. The World Summit in 1993 on social development admitting that the damage of poverty is more considerable on women, and therefore has invited States to commit their resources for the resolution of issues relating thereto. The international conference in 1994 on population and development. The Beijing World Conference on Women in 1995 establishing the analytical perspectives and action plans to ensuring equity and equality between women and men. The Unites Nations conference in 2000 laying down the millennium development goals.
} 
this goal. This document was the policy statement associated with the National Action Plan for the integration of Women in Development ${ }^{4}$ (République du Cameroun, (b)). The seven lines of action emerging from this document stem from twelve points of the Beijing recommendations ${ }^{5}$. In 2002, the National Declaration of Population Policy ${ }^{6}$ (République du Cameroun, (c)) was updated following the International Conference on Population and Development of 1994 and the Millennium Summit in September 2000. It enshrines gender issues as development issues. In addition, it aims to universalise quality primary education, promote functional literacy for people of both sexes and reduce gender disparity in all sectors of economic and social development. In 2003, Cameroon adopted the Poverty Reduction Strategy Document ${ }^{7}$ (République du Cameroun, (d)). Its revision in 2009 resulted in the adoption of the Strategy for Growth and Employment Document (DSCE) ${ }^{8}$ (République du Cameroun, (e)). On this last, the guidelines on equality between women and men are prioritised in the areas of health, education, industry and services, to name a few. For the Government of Cameroon, the DSCE is the foundation supporting all development activities including the main directions of the Gender Policy.

The NGPC of the Republic of Cameroon is seen as a foundational guiding and reference document for government interventions in the field of promoting equality and gender equity. Its development is part of the measures Cameroonian's authorities implemented in the context of strengthening and modernizing the institutional mechanism for the advancement of women. The document's purpose is to promote an egalitarian and equitable society between men and women in order to ensure sustainable development. Its overall objective is to contribute to the systematic elimination of inequalities between women and men at all levels of social life. Its specific objectives are to i) promote equal access for girls, boys, men and women to education, training and information; ii) promote greater access for women to quality health services, particularly in terms of reproductive health; iii) take measures for the elimination of inequalities in the access of men and women to economic opportunities and employment; iv) promote a socio-cultural environment favorable to the development of women and the respect for their rights, v) ensure better representation of women in public life and decision making; vi) accelerate implementation and internalization of legal instruments on women's and girls' rights; vii) and strengthen the national institutional mechanism's capacity to promote women's rights. The NGPC has seven strategic areas of intervention. These are i) the promotion of equality and equal

${ }^{4}$ The original title is "Plan d'Action National d'Intégration de la Femme au Développement" (PANIFD).

${ }^{5}$ i) Improving the living conditions of women, ii) Improving the legal status of women, iii) The valorization of female human resources in all sectors of development, iv) Effective participation of women in decision-making, v) Protection and promotion of the girl child, vi) The fight towards violence against women, vii) Improving the institutional framework for effective ration of women in development.

${ }^{6}$ The original title is "Déclaration de Politique Nationale de Population (DPNP)".

${ }^{7}$ The original title is "Document de Stratégie de Réduction de la Pauvreté (DSRP)".

${ }^{8}$ The original title is “Document de Stratégie pour la Croissance et l'Emploi (DSCE)”. 
access for girls, boys, women and men to education, training and information; ii) improving women's access to health services, especially for reproductive health; iii) promoting equal opportunities and opportunities between women and men in economic and employment; iv) promoting a favorable cultural environment for women's rights; v) strengthening the participation and representation of women in public life and decision making; vi) strengthening institutional frameworks to promote gender issues; vii) improving national legislation on the promotion and protection of women's rights. Each of these axes are matched to specific operational objectives and implementation strategies.

\section{In What Manner Does the NGPC Fit into the Social Reality of Cameroon}

\subsection{The Absence of Knowledge and Awareness about the NGPC by Women's Associations Such as ASMA DLA}

ASMA DLA stands for Douala Mandjara Association. It was legally constituted on June 4, 2012. Its registered seat is located in the city of Douala ${ }^{9}$. This association constituted itself as a network uniting more than one hundred women's associations. Its members come from Bamoun, Bafia and Nso Diasporas; these are ethnic groups originated respectively from the Noun ${ }^{10}$, the Mbam-et-Inoubou ${ }^{11}$ and the Bui $^{12}$ Departments.

The observation of what the social reality within ASMA DLA is, and the close collaboration maintained with the respective offices of all its member associations, offers many insights. Among others, none of the leaders of ASMA DLA and its members associations are informed of the existence of NGPC and in which cases have ever read it. Furthermore, no activity initiated by ASMA DLA for the benefit of its members and their communities is influenced by the guidelines or the action plan defined within the NGPC. Moreover, no ASMA DLA officials have never participated in information sessions (which are believed to exist) offered by various bodies of the state responsible for the vulgarization of NGPC and its programs.

This reality could be explained by the fact that the associative culture in Cameroon is embedded in a paradigm which is a struggle for daily life. Indeed, women's associations, including ASMA DLA, usually have solidarity within the groups as an objective, in order to help each woman face life's challenges in relation to her activities. In other words, the daily life's struggle is so worrying and hard that the intellectual, political and projection side becomes derisory. The demonstration of March 8 is illustrative in this regard. Everything indicates ${ }^{13}$ that this is the only day when the majority of women in Cameroon recalled

\footnotetext{
${ }^{9}$ The original title is "Document de Stratégie pour la Croissance et l'Emploi (DSCE)".

${ }^{10}$ In the West region of Cameroon.

${ }^{11}$ In the Centre region of Cameroon.

${ }^{12}$ In the Northwest region of Cameroon.

${ }^{13}$ If one stands: i) on the countless feasts; ii) on the production and consumption industry which has been developed around this day (as the example of the effigy of the loincloth March 8, which is renewed every year); iii) on the various expressions of moral depravation.
} 
that there is one day of the year which has been devoted to women, although they know very little about what the day signifies. Many of them view that day as simple "Women's day" rather than as a true "International Day for women's rights".

\subsection{Denial of the NGPC by Political Parties}

In most cases, the main actions of political parties revolve around multiple elections because they are more devoted to gaining power. Gender issues then require very little priority. In fact, very few foresee in their program a framework relating to women's issues. An example is the Cameroon Renaissance Movement (C.R.M). In its fundamental preamble text, it states that it wants woman to take an equal share in the duties and responsibilities in the party and later in the government. However, within the five pillars identified as guiding its actions, the issue of women does not actually take a part, according to our point of view.

In fact, almost none of the political parties refer to the NGPC, of which they might not distance themselves, in case one of them arrives at the government position. This raises many questions: To what extent do political parties take into account the documents produced by the State in their daily bustle of life activities? Also for the educational aspect of their militants and the population as well? Are militant women within these political parties imbued with the $\mathrm{NGPC}^{14}$ ? It must be said that many of these political parties show a willful and deliberate rejection of State's documents as these are produced by a power they wish to evict. Thus, the popularization of the State's documents could look like an allegiance. They do not want to risk appearing supportive of the government in power. On one hand, one could talk about the cynical face of the politician politic, and on the other one could say that these political parties have priorities other than the vulgarization of national Cameroonian administration policies. Such an attitude could also proceed from a lack of objectivity.

In any event, the NGPC is part of the documents that bind the Cameroonian State to international institutions. Consequently its denial, in other words, any choice to refute it, becomes a pitfall for its vulgarization and its implementation.

\subsection{What to Say about the Dissemination of the NGPC by the State's Competent Central and Decentralised Services}

Beyond the government that designed the NGPC, which is quite rich in content, the dismemberment of the State, namely all administrations involved in social development such as MINPROFF ${ }^{15}$ and MINAS ${ }^{16}$, seem to work without harmony and without coherence. Consequently, their central and decentralised services are then less able to be tools and instruments for the vulgarization of the

\footnotetext{
${ }^{14}$ Even though this document could have some critical aspects. Nothing is being conceived in an absolute way!

${ }^{15}$ This french acronyme stands for the Ministry of family and women's empowerment.

${ }^{16}$ This french acronyme stands for the Ministry of Social Affairs.
} 
$\mathrm{NGPC}^{17}$. The reality is disconcerting. It reveals that the document is only known within the management's services or the department's services who designed it. If the director and his principal collaborators, who have been at the bottom of the project, come to be assigned elsewhere or dismissed, it will take long for their replacements to catch up. Even more surprising, departmental service chiefs and regional representatives of the relevant ministries do not have great knowledge of this policy in its entirety. So, there is room to question their ability to conduct this policy on the field. What actions do they intend to carry out? Indeed, one would expect that conferences and debates are organised by their bias, in the optic of mentoring women to be aware of the existence of this policy document. To help them understand it and interpret it following their living realities. Even among the elite women in Cameroon, many do not know that there is a national gender policy. The dissemination of the NGPC could therefore be carried through all circumstances conducive to reflection. Here one thinks of the social events around national holidays. One can cite the February 11 Youth Day, May 20 National Day, March 8 International Women's Day. These are opportunities which include weeks of cultural activities. So, one could see as part of the festivities programs, conferences and seminars intended to impregnate the targets of this national policy. A few actions, alas timid, are sometimes carried out.

If the existence of NGPC is unknown to the female population, what about the male, who should also be a relay? If we were targeting, for example, the ruling male elite of the private sector, one might expect that it integrates into its business management metrics inspired by the resolutions adopted by the NGPC.

It must be said that the risk that national policy documents end up being theoretical text fulfilling ministries' drawers and cupboards does not only threatens the NGPC. It also concerns many others such as the Strategy for Growth and Employment Document, the Integration of Women in Development Policy, the National Population Policy, Poverty Reduction Strategy Document, to name but a few. The reality would want that even in the producers' departments all the managerial staff do not possess copies. Ministers, governors and executive directors, would face difficulties to speak about it without been prepared. Well sometimes, they have not even had the opportunity to read the documents.

This fact leads to question the route of the creation of many of those documents whose, one must say, titles very often reflect the jargon of international institutions.

\subsection{Would the Historic Route of the Development of Public Policies Hinder Their Understanding, Their Appropriation and Their Dissemination}

Most of these documents, which symbolise the commitment of the Cameroonian

\footnotetext{
${ }^{17}$ Some key departments must work in harmony in order to ensure the understanding and the vulgarization of the NGPC so as to make sure that it does not end up just being a theoretical paper like many others. Among these ministries are the Ministry of Territorial Administration and Decentralization, the Ministry of Basic Education, the Ministry of Youth and Civic Education, to name a few.
} 
State in the international scene, generally proceed from an initiative of one of the specialised United Nations agencies.

"En plus de la ratification de la quasi-totalité des instruments juridiques internationaux et régionaux de protection des droits de la femme, et de la législation nationale qui ne cesse de se moderniser, le Cameroun (...) confirmait la constance de ses choix, de même que son adhésion irréversible aux options de la communauté internationale dans le domaine" (In addition to the ratification of almost all international and regional legal instruments for the protection of women's rights and the national legislation that is continuously modernised, Cameroon (...) confirmed the stability of its choice, as its irreversible commitment to the options of the international community in the field. Loose translation). (Philemon YANG, prime minister and head of government of Cameroon; excerpt from the NGPC).

In fact, the conception and the realization of such documents, which often end up being national policy, pass through stages that explain the limitations of their long-term vulgarization processes. This is most common when the theme or the philosophy comes from an international organization. Among organizations that are closely concerned of women's issues are UN Women, UNDP ${ }^{18}$. Thus, when a program with a global character is selected to be consolidated and the target populations are targeted, usually experts are committed to produce a strategic framework for the design of the global policy relating thereto. When this design is validated by the sponsor institution's authorities, the general assembly of the said institution adopts a resolution inviting the authorities of the said institution to take all the necessary measures for the implementation of the new program. A related budget is voted upon. The targeted States (African or developing world) are seized for specific meetings relating thereto. Public servants in service at the moment within the concerned administrations are selected. They assist in all the international meetings called on the topic, participate in training seminars and become focal points in their countries. In their turn, they organise internal inter-institutional reflection meetings that open doors to seminars about public sector-private sector-civil society partnership. Seaside towns and cities known for their calmness or their attractivity are targeted for this partnership. The participants, lawyers, doctors, businessmen, academicians or others are sometimes chosen in regard of their connections or their particular relations with the organisers. The meetings may be as many as desired with respect to the importance of the topic or project. The Prime Minister of Cameroon says in the introduction to the NGPC that the document was the subject of a very broad consultation at the national level.

"Bien qu'initié par le Gouvernement, le document a été conçu selon une démarche participative et inclusive. Les organisations de la société civile et les partenaires au développement intéressés ont pris une part active à toutes les étapes du processus de son élaboration" (Although initiated by the Government, the document was developed through a participatory and inclusive approach.

${ }^{18}$ UNDP stands for United Nations Development Programme. 
The organizations of civil society and development partners concerned have taken an active part in all stages of the process of its development. Loose translation). (Philemon YANG, Prime Minister and Head of Government of Cameroon; excerpt from the NGPC).

The above mentioned meetings are conducted through regional seminars often held in towns that are known for their attractiveness. These ones are followed by a national seminar conveyed for the adoption of the final document. Thereafter, this document is transmitted by the government to the sponsoring institution as its strategic manual for the pursuit of the objectives set by the institution in question.

Indeed, the reality as far as the NGPC is concerned reveals that all the managerial staff of the MINPROFF do not have a copy of this document. Consequently, they are less knowledgeable about it. More surprising is the fact that they are the very ones responsible for vulgarizing it. Unfortunately, this reality is similar throughout most of the strategies designed under the impulse of the specialised United Nations agencies. It is therefore not surprising that within ministries having driven a strategy and having participated in the drafting and publication of documents, there are managers or executives who are not impregnated. Many have not had the opportunity to flip through and even less to read.

\section{Critical and Interrogative Approach to the Relationship between Ministries and Associative Groups}

The outcome of fieldwork observation and exploration permit to coach the Mandjara's movement leaders in framing a clear vision, specific goals and culturally appropriate strategies. It is from there that ASMA DLA came into life. Subsequently, the investigation at MINPROFF revealed the ignorance of the existence of this association by this ministry's decentralised services. Hence the initiative to lead the leaders of ASMA DLA group to the MINPROFF in order to create a collaborative bridge between the two parties. Following such an approach nearby ASMA DLA and nearby the competent relevant administrations, how can one believe that such a network can still remain ignored, especially when the NGPC was mainly conceived and elaborated in greater consultation as stated by the Prime Minister and Head of Government of Cameroon in his preface to the national gender policy document?

Beyond the interest of Mandjara movement to bring to the collective consciousness the sibling between the Bamun, Bafia and Nso' communities, it is especially important to see the potential of ASMA DLA as a network of more than one hundred women's associations. Hence the question of why is it that such a network which brings together women from three big departments of Cameroon is not identified as such by the designers and makers of NGPC. Maybe they have conflictual relations with the departmental services? But in total, how could the government successfully implement its programs or its national policies if such groups and targeted populations of such of high importance are disregarded or unknown? What is the relationship that is established between departments and 
associative groups?

It remains that, in Cameroon, associative life is overwhelmingly female. Therefore by extrapolation, the case of ASMA DLA with more than a hundred women's associations, lack of close relationship with policy makers, what about the other associations where very often the majority of members consists of illiterate people! In this framework figure, how can one think that the leaders of associations and their members will know about or understand the NGPC? Even though many of these women are dynamic and committed, they are insufficiently educated to be able to participate in such a policy; to adopt so as to reinterpret it according to the realities and life trajectories of Cameroonian women and men; but also to implement actions related to the programs of the policy.

\section{Conclusions}

This paper demonstrates, largely by taking into consideration the above, that the dynamics in which the National Gender Policy of Cameroon (NGPC) is embedded does not guarantee its social appropriation and its implementation.

Indeed, the women's associations counted among the groups targeted by the NGPC lack knowledge and awareness of this policy document. Political parties, which should relay the dissemination and implementation of measures taken by the Cameroonian State (that bind the State to international institutions), do not take it into consideration. They neither do so in the daily entertainment activities nor in the educational programs of the population and their militants. The majority of the central and decentralised State services' managers, who are tools and instruments of vulgarization of national policy documents, have a limited knowledge of the NGPC. Many of them do not even hold a copy. Furthermore, these services do not always maintain collaborative relationships with some big associative groups. The processes that accompany the development of public policies in Cameroon could be an obstacle to their understanding, their appropriation and their vulgarization.

For this situation to change so that the benefits of NGPC reach women and men from all backgrounds (social, economic, political, and communal) in Cameroon, it would be opportune to take a renewed commitment. On one hand, political parties which cannot distance themselves from the NGPC, should promote it among the female militants. On the other hand, central and decentralised State services, especially those from key ministries involved in social development, could develop more coherent and harmonious strategic partnerships in between them and with associative groups.

This will favor:

- A meaningful understanding of gender equality issues and equity rights which the message is most often misunderstood and misrepresented among the population;

- A better interpretation of NGPC according to the realities and life trajectories of Cameroonian women and men;

- And culturally appropriate strategies for the implementation of NGPC's pro- 
grams.

\section{Acknowledgements}

Warm and sincere thanks to Henri Ntoupendi, Dr Eric Nguwuo' Petuenju', Debbie Coppieters, Julie Saumure and Peter Gibaut for their commitments on reviewing the drafts.

\section{References}

Burkina Faso (2009). Document de la Politique Nationale Genre du Burkina Faso.

Caulier, M. (2014). Les politiques du genre face au conflit. Journal des anthropologues, 1, 303-324.

Egbe Orock, R. T. (2007). Gender Equality-Whose Agenda? Observations from Cameroon. Development in Practice, 17, 93-97. https://doi.org/10.1080/09614520601092220

Foucault, M. (1986). La gouvernementalité in Michel Foucault. Actes (Paris), 54, 6-15.

Foucault, M. (1994). La gouvernementalité. Dits et écrits, 3, 635-657.

République de Guinée (2011). Politique Nationale Genre.

République du Benin (2008). Politique Nationale de Promotion du Genre au Benin.

République du Burundi (2012). Politique Nationale Genre du Burundi 2012-2025.

République du Cameroun (a). Document de Politique Nationale Genre du Cameroun.

République du Cameroun (b). Plan d'Action National d'Intégration de la Femme au Développement (PANIFD).

République du Cameroun (c). Déclaration de Politique Nationale de Population (DPNP).

République du Cameroun (d). Document de Stratégie de Réduction de la Pauvreté (DSRP).

République du Cameroun (e). Document de Stratégie pour la Croissance et l'Emploi (DSCE).

République du Mali. Politique Nationale Genre du Mali (PNG-Mali).

Shore, C. (2012). Anthropology and Public Policy: The Sage Handbook of Social Anthropology (pp. 89-104). Thousand Oaks, CA: SAGE Publications.

Shore, C., \& Wright, S. (1997). Anthropology of Policy: Critical Perspectives on Governance and Power. London: Routledge.

Shore, C., \& Wright, S. (1997). Policy: A New Field of Anthropology. In C. Shore, \& S. Wright (Eds.), Anthropology of Policy: Critical Perspectives on Governance and Power (pp. 3-39). London: Routledge.

United Nations (1975). Declaration of Mexico on the Equality of Women and Their Contribution to Development and Peace. New York, USA.

United Nations (1980). The Convention on the Elimination of All Forms of Discrimination against Women $(C E D A W)$. New York, NY: United Nations.

United Nations (1985). The Nairobi Forward-Looking Strategies for the Advancement of Women. New York, NY: United Nations.

United Nations (1992). Rio Declaration on Environment and Development. New York, NY: United Nations.

United Nations (1993). The Vienna Declaration and Programme of Action. New York, NY: United Nations. 
United Nations (1994). Report of the International Conference on Population and Development, UNFPA. New York, NY: United Nations.

United Nations (1995). Beijing Declaration and Platform for Action. New York, NY: United Nations.

United Nations (2000). United Nations Millennium Declaration. New York, NY: United Nations.

Wedel, J. R., Shore, C., Feldman, G., \& Lathrop, S. (2005). Toward an Anthropology of Public Policy. The Annals of the American Academy of Political and Social Science, $600,30-51$.

Submit or recommend next manuscript to SCIRP and we will provide best service for you:

Accepting pre-submission inquiries through Email, Facebook, LinkedIn, Twitter, etc. A wide selection of journals (inclusive of 9 subjects, more than 200 journals)

Providing 24-hour high-quality service

User-friendly online submission system

Fair and swift peer-review system

Efficient typesetting and proofreading procedure

Display of the result of downloads and visits, as well as the number of cited articles Maximum dissemination of your research work

Submit your manuscript at: http://papersubmission.scirp.org/

Or contact aa@scirp.org 